\title{
Banding on Adolescents: Is Molar Band Height Different than Clinical Crown Height?
}

\author{
Dr Dashrath Kafle,' Dr Aradhana Agarwal,2 Dr Sita Shrestha,,3 Dr Biplov Adhikari4 \\ 'Assistant Professor, 2Lecturer, 3.4Dental Surgeon, Kathmandu University School of Medical Sciences, Dhulikhel, Nepal
}

Correspondence: Dr Dashrath Kafle; email: dashrathoy@yahoo.com

ABSTRACT

Introduction: Bonding of the teeth with brackets have eased the orthodontic procedure. However the bonding of molars is not very successful because of the occlusal force, difficulty in moisture control and age factor. Banding is usually the safe option which is again associated with gingival problems.

Objective: To compare the molar band height with that of adolescent maxillary molar height.

Materials \& Method: A total of 33 maxillary adolescent casts and 30 average sized molar bands were retrieved from the orthodontic clinic of Kathmandu University Hospital. The height of the tooth as well as molar band were measured at 4 different points: mesio-buccal (MB), disto-buccal (DB), mesio-palatal (MP), disto-palatal (DP) and compared with independent t-test by SPSS software. $p$-value was kept at 0.01 for significance.

Result: There is no any statistical significant difference between the tooth and band heights at MB, DB and DP points. The difference is found on only one point MP which is statistically significant.

Conclusion: There is a need of separate molar bands for adolescent patients. The band dimension should be reduced occlusocervically to avoid gingival impingement.

Key Words: banding, bonding, clinical crown height, gingival enlargement

\section{INTRODUCTION}

The usual trend in orthodontics is that comprehensive orthodontic treatment is usually started after the exfoliation of all the deciduous teeth. However sometimes interceptive fixed orthodontic treatment may even be started on mixed dentition period, such as $2 \times 4$ appliances or $2 \times 6$ appliances.' After the invention of dental composite, multi band orthodontic treatment switched into bonding. Usually when we talk about fixed orthodontics, all other teeth except first and second molars are bonded where as those two teeth are banded. In recent years, bonding on molars has gained popularity. However there is a high risk of bonding failure and white spot lesion associated with molar tubes. ${ }^{2-4}$ In a very recent Cochrane review on banding versus bonding, it has been found that there is statistically significant difference on the rate of banding versus bonding failures. According to that review there is $57 \%$ risk of attachment failure in case of bonded tubes whereas the risk is only $25 \%$ in case of banded attachments. ${ }^{5}$ The review also concluded that demineralization on molars is significantly higher on bonded attachment when compared with molar bands cemented with glass ionomer cement. ${ }^{5}$

The third world orthodontics is not yetready to switch into bonded tube especially in adolescent cases because of the lack of cooperation, difficulty in moisture control and small clinical crown height. ${ }^{6}$ Still our major bulk of orthodontic patients are of adolescent age groups. So banding will be done regularly on first and second molar teeth on recent years to come also.

Moreover the bonding failure is more common on those groups. There are various disadvantages of banding versus bonding. Molar bands cause more plaque accumulation, gingival encroachment and gingival inflammation. Gingival inflammation and increased pocket depth is associated with fixed orthodontic therapy. This effect is more commonly seen in adolescent patients. ${ }^{7}$ 
Molar bands are foreign bodies which are inserted in between the contact area mesially as well as distally. It obviously irritates the gingival tissue. However it might not be so evident in case of adult patients because of the increased clinical crown height and well delineated contact. This anatomy is not so evident in adolescents which makes banding a difficult procedure. Because of the dimension of the band, it may even encroach into the buccal as well as palatal gingival tissues which demand trimming the band material on chair side. So the aim of this study is to compare the occluso-cervical height of commonly available maxillary first molar bands with the occluso-cervical height of the maxillary first molar tooth of the adolescent age groups.

\section{MATERIALS AND METHOD}

Total 33 adolescent patients aged 12-14 years were selected retrospectively from the pool of orthodontic patient record from the orthodontic department of Kathmandu University School of Medical Science. The maxillary study models were retrieved from the record and occluso-cervical height was measured at 4 different points; mesio-buccal (MB), disto-buccal (DB), mesio-palatal (MP) and disto-palatal (DP). The maximum cervico-occlusal heights were measured with the help of digital vernier calliper.

Similarly the 30 average sized maxillary first molar bands (Leone, Italy) were selected and the occluso-cervical dimension was measured at four points in the same way like maxillary first molar teeth.

The casts of syndromic patients, patient with cleft lip and palate and without having clear anatomy were excluded from the study. Similarly the bands from two different companies were excluded to reduce the biasness of the study.

The independent t-test was performed to find the significance between the occluso-cervical height of the maxillary firsst molar band and teeth by using SPSS version 16 software.

The sex and side-wise comparison of molar height and width were also done. The p-value was kept 0.01 for statistical significance. The value was kept 0.01 because the difference of even a millimeter can cause significant gingival encroachment.

\section{RESULT}

The group statistics of the maxillary first molar band and tooth is shown in Table 1. The mean occlusocervical measurement of the maxillary first molar tooth as well as first molar bands are shown in the Table 1.

The comparison of height at four different points (Table 1) reveal that there is statistical difference between mean occluso cervical height on MP point $(p=0.000)$. However on rest of the three sites; $M B$, $D B$ and DP, there is not any statistical significance between the occluso-cervical height of the tooth and molar bands. Overall the molar height is slightly greater than that of band. However the mean difference on height is very minimum.

The comparison of occluso-cervical height of the teeth and mesio-distal width of the teeth between male and female group showed significant difference on $M B$, $D B$ and MP sites. However there is not any significant difference between two sexes on DP height and MD width of maxillary first molars (Table 2). Overall male adolescent group have more occluso-cervical height than the female group. There is not any significant difference on mesio-distal width of maxillary molars on right and left sides (Table 3). The group statistics of different sex and side is shown on Table 2 and 3.

The comparison of occluso-cervical height and MD width between right and left side does not show any significant difference.

Table 1: Comparison of occluso-cervical dimension at different points

\begin{tabular}{|c|c|c|c|c|c|c|c|}
\hline Dimension & Tooth/Band & $\mathbf{N}$ & Mean & Std. Deviation & Std. Error Mean & t-value & p-value \\
\hline \multirow{2}{*}{ MB } & Tooth & 66 & 4.9803 & 0.79561 & 0.09793 & 1.803 & 0.76 \\
\cline { 2 - 8 } & Band & 30 & 4.3900 & 0.14615 & 0.05967 & & \\
\hline \multirow{2}{*}{ DB } & Tooth & 66 & 5.0292 & 0.66556 & 0.08255 & 2.166 & 0.34 \\
\cline { 2 - 9 } & Band & 30 & 4.4367 & 0.03386 & 0.01382 & & 0.000 \\
\hline \multirow{2}{*}{ MP } & Tooth & 66 & 6.2508 & 0.61875 & 0.07616 & 7.598 & \\
\cline { 2 - 9 } & Band & 30 & 4.3183 & 0.05913 & 0.02414 & & 0.024 \\
\hline \multirow{2}{*}{ DP } & Tooth & 66 & 4.9762 & 0.70539 & 0.08683 & 2.309 & \\
\cline { 2 - 8 } & Band & 30 & 4.3067 & 0.07866 & 0.03211 & & \\
\hline
\end{tabular}


Table 2: Comparison of tooth height between Male and Female

\begin{tabular}{|c|c|c|c|c|c|c|c|}
\hline Dimension & Sex & $\mathbf{N}$ & Mean & Std. Deviation & Std. Error Mean & t-value & $p$-value \\
\hline \multirow{2}{*}{$M B$} & Male & 26 & 5.3246 & 0.67605 & 0.13258 & 3.004 & 0.004 \\
\hline & Female & 40 & 4.7565 & 0.79474 & 0.12566 & & \\
\hline \multirow{2}{*}{$\mathrm{DB}$} & Male & 25 & 5.2492 & 0.68941 & 0.13788 & 2.167 & 0.034 \\
\hline & Female & 40 & 4.8918 & 0.61970 & 0.09798 & & \\
\hline \multirow{2}{*}{ MP } & Male & 26 & 6.4673 & 0.63252 & 0.12405 & 2.373 & 0.021 \\
\hline & Female & 40 & 6.1100 & 0.57450 & 0.09084 & & \\
\hline \multirow{2}{*}{ DP } & Male & 26 & 5.0615 & 0.58857 & 0.11543 & 0.790 & 0.432 \\
\hline & Female & 40 & 4.9208 & 0.77410 & 0.12240 & & \\
\hline \multirow{2}{*}{$M D$} & Male & 26 & 10.4300 & 0.51204 & 0.10042 & -0.363 & 0.718 \\
\hline & Female & 40 & 10.4900 & 0.73384 & 0.11603 & & \\
\hline
\end{tabular}

Table 3: Comparison of tooth dimension between Right and Left side

\begin{tabular}{|c|c|c|c|c|c|c|c|}
\hline Dimension & Tooth & $\mathbf{N}$ & Mean & Std. Deviation & Std. Error Mean & t-value & $p$-value \\
\hline \multirow{2}{*}{ MB } & 16 & 33 & 4.8855 & 0.85605 & 0.14902 & -0.968 & 0.337 \\
\hline & 26 & 33 & 5.0752 & 0.73103 & 0.12726 & & \\
\hline \multirow{2}{*}{$\mathrm{DB}$} & 16 & 32 & 5.0184 & 0.66270 & 0.11715 & -0.128 & 0.899 \\
\hline & 26 & 33 & 5.0397 & 0.67841 & 0.11810 & & \\
\hline \multirow{2}{*}{ MP } & 16 & 33 & 6.2118 & 0.63320 & 0.11023 & -0.508 & 0.613 \\
\hline & 26 & 33 & 6.2897 & 0.61124 & 0.10640 & & \\
\hline \multirow{2}{*}{ DP } & 16 & 33 & 4.9742 & 0.72312 & 0.12588 & -0.023 & 0.982 \\
\hline & 26 & 33 & 4.9782 & 0.69842 & 0.12158 & & \\
\hline \multirow{2}{*}{$M D$} & 16 & 33 & 10.4755 & 0.64255 & 0.11185 & 0.112 & 0.911 \\
\hline & 26 & 33 & 10.4573 & 0.67073 & 0.11676 & & \\
\hline
\end{tabular}

\section{DISCUSSION}

There is no denial that banding of the molar significantly invites periodontal/gingival problems than the bonding. ${ }^{8}$ However bonding on itself is a very technique sensitive procedure. Bonding on molars have been associated with frequent attachment failures and white spot lesions. ${ }^{2,3,9-11}$ Banding is associated with gingival enlargement and increased pocket depth. 4,8,12-15 The adolescents have more gingival enlargement than the adults. ${ }^{7.16}$ The progress of gingival enlargement into periodontistis is not very common. Gingival enlargement is a reversible process. Many clinicians still prefer to use bands because of its adhesive reliability. ${ }^{17,18}$

There are very few articles which has attempted to find out the causes of gingival enlargement on orthodontic patients. ${ }^{76,19}$ There are limited literature resources which has done comparative studies on adolescent and adult clinical crown heights. However it is generally accepted norm that adult crown is of greater height than the adolescent ones. ${ }^{6}$ We can find many studies on bracket dimension, material, strength as well as base however very few studies have been done on the strength and dimension of molar bands. Banding on adolescent patients is invariably encountered with gingival impingement followed by gingival enlargement. This is because of the reduced clinical crown height on adolescents and increased plaque accumulation near the gingival tissues. Chlorhexidine mouth rinses and gels have been found to reduce the bacterial load and gingival enlargement. ${ }^{20-22}$ The usual clinical method to reduce the gingival impingement is to trim the molar bands occlusocervically on all dimensions. The trimming of molar bands leaves the rough edges which may itself exaggerate the plaque deposition. It is interesting to note the difference between the crown height of adolescents and adults but it is more interesting not to find any difference on occlusocervical heights of bands to be used in adolescents and adults. ${ }^{19}$ If we use the molar band of same height for adolescents and adults, it is more likely that adolescent patients will experience more gingival impingement and enlargement. ${ }^{12}$ 
We have found that the occluso-cervical dimension of commonly available maxillary first molar band and maxillary first molar tooth is same in case of adolescent patient group. So if we use the same band for adult and adolescent then adolescent group have higher chance of developing gingival enlargement because of reduced crown height and gingival impingement by molar bands. This may be the reason that some of the studies have found gingival problem more in adolescents compared with adult group. $7,16,23$

\section{CONCLUSION}

The average maxillary first molar band and adolescent maxillary first molar tooth have similar occluso cervical height. This may increase the chance of gingival encroachment leading to gingival enlargement. So it is recommended that the occluso-cervical height of the molar bands should be smaller for adolescent patient group.

This research opens the door for further researches on molar band dimension to be used in adolescent age group.

\section{OJN}

\section{REFERENCE}

1. Proffit WR FHJ, Sarver DM Contemporary orthodontic appliances and special considerations in treatment for adults. In: Contemporary Orthodontics. 4th ed. St Louis, Mo: Mosby; 2007.

2. Banks P, Macfarlane TV. Bonded versus banded first molar attachments: a randomized controlled clinical trial. J Orthod. 2007 Jun;34(2):128-36; discussion 11-2.

3. Jung M-H. Survival analysis of brackets and tubes: A twelve-month assessment. Angle Orthodontist. 2014;84(6):1034-40.

4. Nazir M, Walsh T, Mandall NA, Matthew S, Fox D. Banding versus bonding of first permanent molars: a multi-centre randomized controlled trial. J Orthod. $2011 ; 38(2): 81-9$

5. Millett DT, Mandall NA, Mattick RC, Hickman J, Glenny AM. Adhesives for bonded molar tubes during fixed brace treatment. Cochrane Database Syst Rev. 2011;15(6).

6. Proffit WR FHJ, Sarver DM Contemporary orthodontic appliances and special considerations in treatment for adults. In: Contemporary Orthodontics. 4th ed. St Louis, Mo: Mosby; 2007:395-430, 635-685.

7. Eid HA, Assiri HAM, Kandyala R, Togoo RA, Turakhia VS. Gingival enlargement in different age groups during fixed Orthodontic treatment. Journal of International Oral Health : JIOH. 2014;6(1):1-4.

8. Boyd RL, Baumrind S. Periodontal considerations in the use of bonds or bands on molars in adolescents and adults. Angle Orthod. 1992;62(2):117-26.

9. Flores-Mir C. Bonded molar tubes associated with higher failure rate than molar bands. Evid Based Dent. 2011;12(3):6400813.

10. Knoll M, Gwinnett AJ, Wolff MS. Shear strength of brackets bonded to anterior and posterior teeth. Am J Orthod. 1986;89(6):476-9.

11. Millett DT, Letters S, Roger E, Cummings A, Love J. Bonded molar tubes--an in vitro evaluation. Angle Orthod. 2001;71 (5):380-5.

12. Alexander SA. Effects of orthodontic attachments on the gingival health of permanent second molars. Am J Orthod Dentofacial Orthop. $1991 ; 100(4): 337-40$.

13. Bollen AM, Cunha-Cruz J, Bakko DW, Huang GJ, Hujoel PP. The effects of orthodontic therapy on periodontal health: a systematic review of controlled evidence. J Am Dent Assoc. 2008;139(4):413-22.

14. Bondemark L. Interdental bone changes after orthodontic treatment: a 5-year longitudinal study. Am J Orthod Dentofacial Orthop. 1998;114(1):25-31.

15. Demling A, Heuer W, Elter C, Heidenblut T, Bach FW, Schwestka-Polly R, et al. Analysis of supra- and subgingival long-term biofilm formation on orthodontic bands. Eur J Orthod. 2009;31 (2):202-6.

16. Hamp SE, Lundstrom F, Nyman S. Periodontal conditions in adolescents subjected to multiband orthodontic treatment with controlled oral hygiene. Eur J Orthod. 1982;4(2):77-86.

17. Keim RG, Gottlieb EL, Nelson AH, Vogels DS, 3rd. 2008 JCO study of orthodontic diagnosis and treatment procedures, part 1: results and trends. J Clin Orthod. 2008;42(11):625-40.

18. Keim RG, Gottlieb EL, Vogels DS, 3rd, Vogels PB. 2014 JCO Study of Orthodontic Diagnosis and Treatment Procedures, Part 1: Results and trends. J Clin Orthod. 2014;48(10):607-30.

19. Diedrich P, Rudzki-Janson I, Wehrbein H, Fritz U. Effects of orthodontic bands on marginal periodontal tissues. A histologic study on two human specimens. J Orofac Orthop. 2001;62(2):146-56.

20. Diamanti-Kipioti A, Gusberti FA, Lang NP. Clinical and microbiological effects of fixed orthodontic appliances. J Clin Periodontol. $1987 ; 14(6): 326-33$.

21. Huser MC, Baehni PC, Lang R. Effects of orthodontic bands on microbiologic and clinical parameters. Am J Orthod Dentofacial Orthop. 1990;97(3):213-8.

22. M F. Soft-isue maintenance during orthodontic treatment. Available at htp:/www.inedce.com/courses/1485/pdf/softis uemaintenance. pg.1-10 [Last Acesed on 2013 Sep 17.

23. Thornberg MJ, Riolo CS, Bayirli B, Riolo ML, Van Tubergen EA, Kulbersh R. Periodontal pathogen levels in adolescents before, during, and after fixed orthodontic appliance therapy. Am J Orthod Dentofacial Orthop. 2009;135(1):95-8. 
12. Alexander SA. Effects of orthodontic attachments on the gingival health of permanent second molars. Am J Orthod Dentofacial Orthop. 1991;100(4):337-40.

13. Bollen AM, Cunha-Cruz J, Bakko DW, Huang GJ, Hujoel PP. The effects of orthodontic therapy on periodontal health: a systematic review of controlled evidence. J Am Dent Assoc. 2008;139(4):413-22.

14. Bondemark L. Interdental bone changes after orthodontic treatment: a 5-year longitudinal study. Am J Orthod Dentofacial Orthop. 1998;114(1):25-31.

15. Demling A, Hever W, Elter C, Heidenblut T, Bach FW, Schwestka-Polly R, et al. Analysis of supra- and subgingival long-term biofilm formation on orthodontic bands. Eur J Orthod. 2009;31 (2):202-6.

16. Hamp SE, Lundstrom F, Nyman S. Periodontal conditions in adolescents subjected to multiband orthodontic treatment with controlled oral hygiene. Eur J Orthod. 1982;4(2):77-86.

17. Keim RG, Gottlieb EL, Nelson AH, Vogels DS, 3rd. $2008 \mathrm{JCO}$ study of orthodontic diagnosis and treatment procedures, part 1: results and trends. J Clin Orthod. 2008;42(11):625-40.

18. Keim RG, Gottlieb EL, Vogels DS, 3rd, Vogels PB. 2014 JCO Study of Orthodontic Diagnosis and Treatment Procedures, Part 1: Results and trends. J Clin Orthod. 2014;48(10):607-30.

19. Diedrich P, Rudzki-Janson I, Wehrbein H, Fritz U. Effects of orthodontic bands on marginal periodontal tissues. A histologic study on two human specimens. J Orofac Orthop. 2001;62(2):146-56.

20. Diamanti-Kipioti A, Gusberti FA, Lang NP. Clinical and microbiological effects of fixed orthodontic appliances. J Clin Periodontol. 1987;14(6):326-33.

21. Huser MC, Baehni PC, Lang R. Effects of orthodontic bands on microbiologic and clinical parameters. Am J Orthod Dentofacial Orthop. 1990:97(3):213-8.

22. M F. Soft-isue maintenance during orthodontic treatment. Available at htp:/www.inedce.com/courses/1485/pdf/softis vemaintenance. pg.1-10 [Last Acesed on 2013 Sep 17.

23. Thornberg MJ, Riolo CS, Bayirli B, Riolo ML, Van Tubergen EA, Kulbersh R. Periodontal pathogen levels in adolescents before, during, and after fixed orthodontic appliance therapy. Am J Orthod Dentofacial Orthop. 2009;135(1):95-8. 